\title{
The Roots of Tension in South Caucasus: The Case of Iran- Azerbaijan Relationship
}

\author{
Abdollah Baei lashaki ${ }^{1}$, Masoumeh Rad Goudarzi ${ }^{1} \&$ Davood Amraei ${ }^{2}$ \\ ${ }^{1}$ Department of Political Science, Faculty of Humanity, University of Guilan, Iran \\ ${ }^{2}$ Department of Political Science, Faculty of Law and Political Science, Islamic Azad University, Iran \\ Correspondence: Masoumeh Rad Goudarzi, Department of Political Science, Faculty of Humanity, University of \\ Guilan, Tehran Road, Rasht, Iran. Tel: 98-911-150-0260. E-mail: fr.raad1@gmail.com
}

Received: August 18, 2013 Accepted: October 28, 2013 Online Published: November 29, 2013

doi:10.5539/jpl.v6n4p141 URL: http://dx.doi.org/10.5539/jpl.v6n4p141

\begin{abstract}
Iran and Azerbaijan are key countries in the Caspian Basin, thanks to their historical continuity, religious and cultural similarities, shared energy resources and strategic position. However, since the independence of Azerbaijan, complex and contradictory interactions have shaped their relationships, influencing the region dynamics. However, in initial stages, political and ideological differences affected the ties, but impacts of sharp increase in geopolitical importance of Caucasus and Caspian Basin in past two decades and role of external factors could not be ignored. Forming of new borders and political blocks as well as reaching energy resources made the region focal point of world geopolitics and provided grounds for intervention of regional and trans-regional powers, aiming to attain their security, political and economic goals and interests. This study examines security, political and economic factors in both internal and external levels, which have contributed in extension of the conflicts between Iran and Azerbaijan in the past two decades.
\end{abstract}

Keywords: south caucasus, roots of tension, Iran foreign policy, Republic of Azerbaijan, regional players, trans regional players

\section{Introduction}

As one of the strategically important regions of the world, Caucasus has special kind of geography. The area is connected to the Caspian Sea from the East, the Black Sea from the West, the plains of southern Russia from the north and, Iran and Turkey from the south. The region connects Asia and Europe both in North - South and East - West axes. It is also the center area of the confluence of two great religions; Islam and Christianity. Geographical structures of the area and the large amounts of energy have doubled its importance in the world. The research from the amount of oil reserves in the region have shown equal to the North Sea. Energy and security are two important axes in the future developments of the region (Ghysari \& Goudarzi, 2009:122). Caucasus for many reasons, including close proximity to the Caspian Sea and in terms of geographical location and transit of energy resources has a great geopolitical importance for the West. The combination of these factors is the reason why it has attracted the major and international powers attention (Dehgani Firouzabadi, 2010: 209). After the fall of Soviet Union, Iran encountered some newly formed countries and developed its relationships with them especially the Shiite-majority Azerbaijan, which was a part of Iran until 1828 and had the vast historical and cultural ties between the two countries. One important event made this region more important; Nagorno-Karabakh Crisis. In 1991, the population of approximately 150 thousand Armenians living in Nagorno-Karabakh declares a self-declared republic, which leaded to a bloody crisis between the two neighboring countries: Azerbaijan and Armenia. During the war, based on political, ideological, economic and security reasons, different countries supported Armenia or Azerbaijan. As a neighboring country, Iran tried to intervene and settle the disputes because peace and security in the region was a guarantee for Iran's security in northern borders. Despite Iran's mediation attempts to solve the conflict, the major powers especially Russia at the time had no tendency to see Iran's dominance over region, therefore the mediatory initiatives had any results. By being defeated in negotiations, Azerbaijan accused Iran for intruding in war and supporting of Armenia. However, the backgrounds for controversies can be traced back in the first sight of Azerbaijan's Independence. Although Iran recognized Azerbaijan immediately and elevated the relationships from consulate to embassy, the controversies have continued over legal jurisdiction of Caspian Sea and the western tendencies of Azerbaijan 
Republic (Afrasiabi \& Maleki, 2003:258). Despite efforts to reduce the disagreement between the two countries, sometimes one country condemns another for intervening in internal affairs and supporting terrorist groups. However, in the South Caucasus, Armenia and Iran have warm relationship and attempt to extend it to higher level.

The power vacuum appeared immediately after collapse of Soviet Union and a range of crises in Caucasus made this region a competing place for regional and trans-regional powers in order to gain maximum political, economic, and ideological benefits. Iran foreign policy and level and depth of relationship with South Caucasus countries was affected enormously by adopted policies and behaviors of regional and trans-regional powers in past two decades, while geographical realties of the region shows that Iran relationships with South Caucasus countries have the capacity to be elevated to a strategic level (Koulai, 2010: 82).

The main question of this article is what are the internal routs of the tension between two countries, though there are cultural, historical, and religious ties? In addition, how the goals and interests of regional and trans-regional powers have depended and broadened the controversy? Researchers will attempt to address the subject by using analytic-descriptive method. To do so, the factors affecting the formation and deepening of the crisis in the internal, regional, and extra-regional levels will be discussed.

\section{Conflicts in Bilateral Relations at the Domestic Level}

Azerbaijan Republic declared independence on 30 August 1991 and the constitution of the country confirmed in November 12, 1995 by $91 / 9 \%$ of the voters. Iran was one of the first countries, which recognized its independence. Both countries have had commonalities of culture, history, and religion, and the relationship between them would have a high level of regional and international cooperation. However, a series of legal, political, ideological, and economical dispute ties with their relationships.

In addition to the issue of Iran's position on the Nagorno-Karabakh conflict, which was discussed briefly in the introduction, the issue of relations between Iran and Armenia has always been sensitive for Azerbaijan. Iran recognized the Republic of Armenia just three months after the independence. In 1992, due to border security and political interests in the region and for development of economic, politics and cultural relations between two countries, Iran established a diplomatic relations with Armenia. Iran has considered Armenia because of geopolitical position as a key gate for accessing to South Caucasus and European countries. Iranian authorities hope that close ties with Armenia pave the ground for their country to plays an more effective and extended role in the region (Ghysari, 2009: 130). On the other side, because of lack of rich energy resources, non-accessibility to free waters, and deep racial-historical conflicts with both Azerbaijan and Turkey, Armenia has been pushed toward Iran too (Sadegh-Zadeh, 2008: 3). Azerbaijan considers Iran's tie with Armenia as a sign of enmity and it is always a shadow on relations between the two countries.

The issue of Caspian Sea legal regime and its shares for each country, and disagreement over energy sources and their transmissions are the other issues that have made some controversies between the two countries (Bandy, 1998:15). The definition of Azerbaijan for sharing Caspian Sea is exploiting of Sea from the coast of the each country to the middle point of the Sea (a point equal to all coastlines) (Yakushik, 2006). Iran's definition of the legal regime of the Caspian Sea is the antithesis of the Republic of Azerbaijan's thesis. Iran believes in the principle of fair use. In this principle, Iran emphasizes on this point that any share should consider the seabed, and the special characteristics of the Sea such as: shape of the sea, length of the sea and the distribution of energy sources. Therefore, for achieving a fair division, these features should be considered (Mirfakhrai, 2004:180-88). It should be noted that the disagreement over definition of the legal regime of Caspian Sea, is not only limited to Azerbaijan, but to the other Caspian countries. However, due to having common oil and gas resources in the disputed area between the two countries, it is more obvious and serious. It's noteworthy to mention that Caspian region has the third largest oil and gas reserves after the Persian Gulf and Siberia which its estimated energy sources is about 4 percent of global reserves (Bp, 2006).

In addition to legal disputes over the past two decades, Azerbaijani government has repeatedly accused Iran of destabilizing of country's security by organizing and support of opposition's parties particularly Islamist groups in order to increase its influence. However, it seems that the roots of Azerbaijan political problems should be sought within the country. Since independence, the political system has an authoritarian trend. For two past decades, the monopoly of power in Azerbaijan has remained in the hand of Aliyev family. From 1993 to 2003, Heydar Aliyev and since 2003 President Ilham Aliyev have held political power. Monopolizing of power by the ruling party of New Azerbaijan and handling of all official posts, caused dissatisfaction between both the liberal and Islamic parties. Ilham Aliyev's government because of the secular and anti-religious policy, and failing to comply with democratic norms and principles, has been criticized, in respect, by Islamist and Liberal parties. 
Although Azerbaijan is known as a country with a majority Shiite Muslim (second Shia majority country in the world after Iran), but the country's governmental system is based on the separation of religion and politics (Mojtahedzadeh, Hossein Pourian and Karami Pour, 2007:219). Secularist policies of the past two decades are the official policies in domestic affairs; but process that occurred over the past few years was far beyond the Azerbaijan government's known policy. These actions provoked outcry of Muslims in the country, asking for more religious and political freedom. Official actions such as banning the veil in schools, universities and official administrations, banning of broadcasting the call to prayer from mosques and official bans prohibiting the students and young people from entering mosques, closing the religious schools, threatening the students who have studied in Iran's seminaries, made great disappointment among domestic and outside circles.

Table 1. Estimates of oil and gas reserves and resources

\begin{tabular}{ccccc}
\hline \multirow{2}{*}{ Region } & Country & \multicolumn{2}{c}{ Proven Reserves, BP, End of2005 } & Possible Additional \\
\cline { 3 - 4 } & & Oil (billions of bbl.) & Natural Gas (trillion tcf) & Oil/Gas EIA \\
\hline \multirow{2}{*}{ Caspian Sea } & Azerbaijan & 7.0 & 48 & $32 / 35$ \\
Kegion & Iran & 0.1 & n.a. & $15 / 11$ \\
& Russia & 39.6 & 106 & $92 / 88$ \\
& Turkmenistan & 0.3 & n.a. & $7 /$ n.a. \\
& TOTAL & 47.5 & 102 & $38 / 159$ \\
Reference & United States & 29 & 257 & $184 / 293$ \\
Areas & North Sea & 14 & 193 & $47 / 271$ \\
& Saudi Arabia & 264 & 162 & n.a. \\
& WORLD & 1,201 & 244 & n.a. \\
\hline
\end{tabular}

CRSR report for Congress Order Code RS21190 September 8, 2006

Azerbaijan policy for establishing of close ties with U.S. and Israel also has made negative effects on the country's relations with Iran (Koulai, 2010: 87). U.S. and Azerbaijani military cooperation, has provided the possibility of using its territory by U.S. to attack Iran in a possible war and it has increased Iran's sensitivity of their military ties. With increasing pressure from international community about Iran's nuclear programs, the cooperation between the governments of Azerbaijan, the United States, and Israel has grown. Classified documents released by Wiki Leaks in April 2011 revealed that the territory of Azerbaijan used by Israel over the past 4 years for spying on Iran. The simultaneity of these actions and terrors of Iranian nuclear scientists made Iran to accuse Azerbaijan of helping Israel and therefore Iran has summoned the Azerbaijan's ambassador and announced its dissatisfactions. Furthermore, installation of American missile defense shield and allowance of refugee to Mujahidin if they expel from Iraq made the relationships more controversial.

In the coming pages the researchers will investigate how and in what extend the different goals and interests of regional and Trans- regional powers affected continuation and extension of dispute between two countries? To do so, the focus is on the role of Turkey and Russia as main regional powers and players and Israel and the United States as Trans- regional powers and players.

\section{The Causes of Tension in Regional Level}

\subsection{Turkey}

For understanding the role of Turkey in continuation and extension of the crisis in Azerbaijan - Iran relationships, we should understand the foreign policy of Turkey and its role in Caucasus region in two different stages: before 2002 which country ran by secular parties and then, since 2002 that Justice and Development Party took office by a general election and Turks have looked for a more dynamic role in region, sometimes called New Ottamanism in academic circles (Fisher Onar, 2009 and Taspinar, 2011). In the first stage, Turkey's foreign policy orientation known as Kamalism was based on the following six principles upon, and regional issues were not a priority in the country foreign policy: 1- Nationalism 2- Secularism 3- Republicanism 4-Populism 5Statism 6- Reformism. These characteristics primarily made Turkey to avoid from regional issues and secondary made it closer to West with the aim of enjoying their economical and political capabilities in order to be known as a European country (Omidi and Rezai, 2011:236-237). In 1990s coincided with the rise of the independence of former Soviet republics and Turgut Özal came to power in Turkey. Turkey was one of the first countries, which recognized the independence of the new republics and was glad to see five new countries with Turkish 
language and many historical and cultural similarities, considering them as new ways for spreading its dominance over the region (Aras, 2009:67). It had been considered that after the Cold War, the importance of Turkey would be decreased in the region (Aydin, 2002:39). The cultural commonalities between these newly formed countries with Turkey caused the revival of Turkish influence in the region (Karakoc, 2009:59). This country looks for opportunities and interests in region especially in the South Caucasus. Strategic alliance with the U.S. is the first goal that can be seen in the region for Turkey. U.S. led NATO forces needs allies to expand its influence. Accordingly, Turkey is one of the countries considered by the United States to play a significant role in the region and at the same time uses the benefits of it (Hashemi, 2005: 137). There are several factors for Turkey to consolidate its relations with the Turkish Republics. These factors are: unity in race and religion as well as filling the power gap after the fall of Soviet Union in region. There is also a competition with other countries, including Iran and Russia to have more influential role in Caucasus.

After collapse of Soviet Union and defeat of communist ideology, both Iran and Turkey began an ideological competition for influence over the South Caucasus and Central Asia. In this competition, Iran considered itself as representative of Islamic ideology and Turkey on the other side considered itself as the representative of secular and liberal ideology. However Islamists came to power in Turkey in 2002, and the anti-religious position of the Turkish government became less ideological but the competition between the two countries continued in other areas (Rafi and Mazloumi, 2012:89). In that, area Iran was seeking its revolutionary lines in region, while Turkey was following its national policies and had defined a secular role for itself.

For Turkey, the Caucasus, and especially Azerbaijan, is an entrance gate to the Caspian Sea and Central Asia (Sinkaya, 2005: 12). Among all the other countries, which gained their independence, Azerbaijan is the closest in just language, culture, and ethnic to Turkey. The oil pipeline and energy sources in Azerbaijan were good reasons for Turkey and Iran to compete over. This geopolitical and economic competition was obvious over Nagorno-Karabakh conflict and in energy transmission route. Iran opposed the construction of the Baku - Tbilisi - Ceyhan pipeline, while the Turkish efforts reached its maximum to establish this direction as the main energy transition line. From Iran's point of view, the Azerbaijan oil pipeline route from Iran also means a lever for controlling the behavior of Baku. One of the major concerns of Iran at this regard is the provocation of Iranian Azeri as an ethnic minority by the Azerbaijan's government, which is seeking for an independence movement, or annexation of the territory to Azerbaijan.

Turkey's competition is economic, ideological with Iran, and political with Russia. Western governments have supported this competition in order to make obstacle in Iran and Russia's way of influencing the region. Turkey is following a policy of provoking the Turkish language countries such as Azerbaijan in order to take the rein of leadership in this region (Afshordi, 2002:271). On the other side Iran fixes its role according to existing realities in this area and looks for a multi-facet role; in this regard, Iran's role to establish new organizations such as the Caspian Sea Cooperation Organization could be noticed (Mousavi, 2009:8). Although both countries are looking for influence on Azerbaijan according to their security and national policies, Turkey is more successful than Iran due to its language similarities and provocation of this country to attract their people (Aydin, 2002:40).

The follow are how Turkey's policies in Caucasus for reaching its goals and interests have affected controversies between Iran and Azerbaijan:

1. Iran and Turkey compete for being known as the dominant power in region. In this competition, Turkey does its best to prevent Iranian model of political Islam by looming an ideological competition of Iran in Azerbaijan. In this regard, the Turkish influence in Azerbaijan is working by promoting pan-Turkism and representing its governance model in order to eliminate Iran from this competition.

2. The other reason, which prevented Iran's influence in region and made conflicts between Iran and Azerbaijan is Nagorno-Karabakh crisis. In this crisis, Iran attempted to intervene the crisis, but in that time, Turkey was discontent with Iran's intervention and knew that as opposing to its own policies; therefore, Iran was eliminated from peace negotiations.

Due to the opportunities lying ahead for them, Turkey is looking for the following purposes in the region:

1 Representing its own governmental model to Azerbaijan

2 Expanding Pan-Turkism

3 Becoming the political and economic bridge between West and the region

4 Preventing expansion of Islamic Fundamentalism 
According to what has been said, Iran's unstable relationships with region's countries, especially Azerbaijan, have given the best opportunity to Turkey in order to develop its influence. In the absence of a serious competitor, Turkey can expand and deepen its influence in the South Caucasus.

\subsection{Russia}

A glance at the history of Caucasus reveals that the region has been under the influence of three regional countries: Turkey, Iran, and Russia. However, during recent decades, especially after the collapse of the Soviet Union, other European and western countries, especially the U.S., have been trying to penetrate in the area. In early nineteenth century, Russia occupied the Caucasus and Iranian influence as a dominant power in the region reduced gradually. However, after the collapse of the Soviet Union an opportunity was provided for Iran to retain its influence in South Caucasus, try to form high-level political and economical relationship with the newly independent countries in the Caucasus and Central Asia.

Russians knows Caucasus as the "near abroad" and the region has great importance for them due to its strategic, geopolitical and security condition. As a result, they have recognized and defined substantial national interests in the region (Firouzi, 2010: 95). At first Russia had a moderate look to the West but after Vladimir Putin came to power, the policy of this country has gradually changed. At this stage, Iran and Russia have considered the U.S. as a common enemy; therefore, Russia opened some ways for Iran in the region. However, that was not a reason for Russia for not viewing Iran as a rival power due to the following reasons:

A. Caucasus and Central Asia has long been considered as the exclusive domain of Russia dominance and their backyard; therefore, they do not want see any other rival country in this important area.

B. Regional countries are looking for alternative countries instead of Russia to exchange energy sources and expansion of economic trades, which caused the Russia's sensitivity in the area.

Russia has no positive look to Iran to participate in the future of the region. In this regard, it can be noted the prevention of Iran from engaging in certain oil and gas projects in the region. However, about the fact that Russia can affect the relations between Iran and Azerbaijan, we should note that:

1. Russia used the Nagorno-Karabakh Conflict as an instrument to influence the relations between Iran and Azerbaijan. Nagorno-Karabakh Conflict gave this advantage to Russia to eliminate Iran from competition and makes a wide relationship with Azerbaijan. Although Russia introduces Iran as an important player in the region, in practice it wants to put Iran away from competition. Particularly in relation to the Nagorno-Karabakh conflict and Iran's failure to mediate between the two warring sides, Baku knows Iran responsible for Azerbaijan failure in war with Armenia.

2. The other issues that Russia has used to intervene about Iran- Azerbaijan relationship are the legal regime of Caspian Sea and put Caucasian countries under pressure to put Iran away from transmission of energy sources plans. As it put pressure on its ally Armenia to cut its economic and energy cooperation with Iran. For example, Russia made barriers for Iran in order to stop this country from making oil refinery in Armenia and it finally yielded to Russia (Atai, 2011:132). About legal regime of Caspian Sea, it should be noted that Iran and Russia were both on one side because they believed that Caspian Sea is not a true sea but a lake, so it does not included in Free Water's laws, but eventually Russia supported Azerbaijan's plan and left Iran alone.

\section{The Causes of Tension in Trans-Regional Level}

\subsection{Israel}

Israel, in the past two decades, has been creeping for influence on the Caucasus. The country has two main objectives in the region: the pursuit of ensuring its national interests in the Caucasus and to weaken Iran's influence in the region, as their archenemy. Therefore, after the independence of Azerbaijan, Israel tried to form warm and extended ties with the country. One of the main reasons behind such a ties is guarantee of Israel direct presence in a country with long border with Iran; Country which Tel Aviv remembers it as its main enemy. Israeli authorities strongly believe that Iran having historical, religious, cultural, and geographical similarities with Azerbaijan can create a united front against Zionism. Therefore, have tried introduces Iran as a serious threat to security and stability of Azerbaijan (Vosoughi, 2008: 110). Another reason that can be cited for Israel's presence in the region is a large population of Jews in south Caucasus specially Azerbaijan.

Israel's relations with Azerbaijan can be reviewed within the framework of Ben-Gurion, Israel's first president. According to him, Israel should from and extend its ties with the surrounding non-Arab countries. Because Israel had no opportunity to collaborate with Arab neighbors, it had to make an alliance with Iran, Turkey, and Ethiopia. However, the Islamic Revolution of Iran left these efforts fruitless. Since that, one of the priorities of 
Israel foreign policy in the region was making relation with moderate Islamic countries. After collapse of the Soviet Union and the formation of new republics in the Caucasus, Israel has had a hard competition with Iran to have more influential role in the region and prevent the threat of Islamic fundamentalism. The country has tried hard to show the threat of Islamic fundamentalism worse than communism. Israel's relations with the new independent countries fulfilled David Ben-Gurion strategy (Karami, 2007:46), but its presence in Azerbaijan has faced opposition from Iran and made some conflicts between the two countries. The two states signed a military cooperation treaty, and Israel provides the Azeri military with the bulk of its equipment - a relationship capped by a \$1.4 billion deal for drones and air defense equipment between Israeli Aerospace Industries and Baku, announced in January 2012. Many Israeli advisors, trainers, and technicians work in Azerbaijan supporting this relationship. For Iran, the main purpose of Israelis authorities to form close ties with the Republic of Azerbaijan is having direct access to Iran's borders, a concern that Iranian authorities have shared it with Azerbaijani's counterparts repeatedly.

Apart from the security issues, the support for the opening of the Baku-Ceyhan pipeline has continued the tensions between Iran and Azerbaijan. The opening of this pipeline can reduce the geopolitical role of Iran (Gholizadeh and Zaki, 2008:36) and can give United States and Israel this opportunity to take the control of energy sources. Accordingly, Israel presence in Azerbaijan can affect the relations between Iran and Azerbaijan in two different ways:

1. Iran's concerns because of Israel presence in the region; Iran is concerning about the military and security agreements between Israel and Azerbaijan. The obvious examples of these concerns are that Iran claims Israel is using this territory for espionage and assassination of its nuclear scientists.

2. Economic and Cultural Cooperation between Israel and Azerbaijan; Israel is the second largest oil importer from Azerbaijan and by the operation of the pipeline Baku - Tbilisi - Ceyhan it will become the largest gas importer from Azerbaijan. In the field of cultural relations, Azerbaijan has become the only Muslim country where in the Satanic Verses is printed. Quds Day rally is prohibited while the Holocaust commemoration is held. Two countries have signed an agreement of co-production and sale of military equipment. More broadly, Israel has been among Azerbaijan's top five trade partners in recent years.

\subsection{United States}

United States is the largest trans-regional power in the Caucasus region and has identified a variety of substantial interests and role for itself in the region. The U.S. considers Central Asia, Caucasus, and Caspian Basin as strategic zone due their geopolitical and economical situation especially long borders with Russia and great amounts of oil and gas reserves. Collapse of the Soviet Union provides a great opportunity for the U.S to play a more active role in the post-Soviet Caucasus region, especially the South Caucasus. The U.S. has an eye on the South Caucasus and South Caucasus linkage with Iran and has always tried to minimize and even eliminate Iran's influence from the region (Vosoughi, 2008:109). The country is looking for expanding its economic ties while having a lever for controlling Russia, China, and Iran (Nicu Sava, 2004:16). By entering the regional countries into security plans and expanding NATO to the East, the U.S. has formed military alliances with countries in the region and has expanded its influence for a long period.

A- The U.S.'s most important goals in this area can be classified as:

B- Accessing to the oil and gas resources and control over its extraction and export

C- Accessing to regional markets and expanding its business ties

D- Fighting Russia and Iran influence in the region

E- Strengthening security ties with countries in the region for a long period (Amirahmadian, 2009: 89-90).

The U.S. policies made some other conflicts between Iran and Azerbaijan over last two decades:

1. Supporting for Azerbaijan to join NATO; joining the NATO alliance will surround all northwestern borders of Iran and will provide the U.S. presence in the area. NATO joint military operations in Azerbaijan have expanded Iran's concerns.

2. Making the military bases in Azerbaijan territory also caused Iran's dissatisfaction. In 2003, the U.S. made some negotiations in order to build a number of military bases in Azerbaijan and in 2005 Baku confirmed that U.S. had located two radars in its borders (Chaboki, 2009:75). In the course of past years, U.S. has increased its military and security cooperation with Azerbaijan gradually.

3. Eliminating Iran from Caspian Sea oil and gas projects, the U.S. understands that as much as the energy transmission ways are versatile, the western energy supplies will be more secure. The U.S attempted its best and did not allowed Iran to have the pipeline in its land; rather they preferred to make Baku-Tbilisi Ceyhan pipeline. 
Naturally, the greater the conflict is, the opportunity for the U.S. government to use its influence in the region will increase, and it is a threat for both Iran and Russia.

\section{Conclusions}

The geopolitical and geostrategic position of Caucasus in vicinity of Europe, Russia, central Asia, and Middle East and the energy sources and markets and financial interests have made the region more and more important. These national interests include the ideological, political, economic, security, military and cultural interests. Particular demographic, historical, linguistic, racial, religious, and cultural and its special geographical location added to the complexity of the region. All of these elements provided a competition floor for regional and extra-regional powers in the Caucasus. Although Iran and Azerbaijan have cultural and historical backgrounds, from the beginning, they faced many difficulties in their relationships, different attempts of governments fail to reach a compromise, and the tensions remain. Iran and the Azerbaijani conflict rooted partly in intra-regional factors and domestic policies adopted by each country, which include the ideological conflicts and disputes (legal regime of the Caspian Sea and the Nagorno-Karabakh conflict). This depth of conflicts depends on the role and policies of other actors in the region. Roles of major powers such as Russia and the United States to influence the political, economic, and military targets in the area and variety of other actors such as Israel and Turkey over the long-term trajectory will cast shadow on relations between Iran and Azerbaijan. The ideological struggle even by assuming policy changes in Iran, the United States and Israel and their relations toward each other cannot completely shade away from the region and both countries. Aside from these ideological conflicts, the geopolitical and geostrategic realities in region according to economic and financial opportunities make this notion that we cannot expect the reduction of conflicts in the Caucasus in general and the crisis between Iran and Azerbaijan in particular.

\section{References}

Adler, A. (2004, April). La Turquie En Europe Plaidoyer Pour Une Integration. Le Figaro, 21.

Afrasiabi, K., \& Maleki, A. (2003). Iran's Foreign Policy after 11 September. The Brown Journal of World Affairs, Ix(2), 255-265.

Afzali, R., Rashidi, M., \& Motaghi, A. (2012). Analysis of Iran and Azerbaijan Mutual Relationship Structure from 1991 to 2010 with Geographical Constructivism Perspective. Human Geography Researches, 80, 1-19. [Persian]

Amirahmadiyan, B. (2009). Analysis of Reasons and Effect of United State of America's Presence in Caucasus. Geopolitics Quarterly, 5(2), 66-97. [Persian]

Aras, B. (1998). Post-Cold war Realities: Israel's Strategy in Azerbaijan and central Asia. Middle East Policy, 5(4), 68-81. http://dx.doi.org/10.1111/j.1475-4967.1998.tb00370.x

Aras, B. (2003). Turkish Foreign Policy towards Iran Ideology \& Foreign Policy. Journal of Third World Studies, xviii(1), 105-124.

Atai, F. (2012). Iran and South Caucasus Countries. Central Eurasia Studies, 5(10), 119-136. [Persian]

Aydin, M. (2002). Turkish Policy toward the Caucasus. The Quarterly Journal, 1(3), 39-47.

Bandy, C. W. (1998). The Caucasus Region and Caspian Basin: Change Competition and Challenge. Conflict Studies Research, 36, 1- 28.

BP Statistical Review of Word Energy. (2006).

Caspian Sea Region: Survey of Key Oil and Gas Statistics and Forecasts. (2006 July). U.S. Geological Survey. National Oil \& Gas Assessment.

Chaboki, U. (2009). Iran and Azerbaijan Relationship Challenges. Central Eurasia Studies, 2(6), 63-84. [Persian]

Darvishi, F., \& Fardi, M. (2008). National Interest Definition in Iran's Foreign Policy, a Case Study from Khatami's Government: 1997-2005. Geopolitics Quarterly, 4(3), 102-136. [Persian]

Dehgani Firouzabadi, S. J. (2010). Iran's Security Policies in South Caucasus. Geopolitics Quarterly, 6(1), 208-239. [Persian]

Emadi, S. E., \& Nezhad, H. (2011). Energy Market for Caspian Sea Oil and its Supply. IBSU Scientific Journal, $5(2), 21-34$. 
Etaat, J., \& Nosrati, H. R. (2009). Iran and Caspian Sea Basin Energy Transformation. Central Eurasia Studies, 2(3), 1-22. [Persian]

Firouzi, R. (2010). Impact of Russia on Caucasus Region Countries Foreign Policy. Central Asia and Caucasus Studies, 70, 91-116. [Persian]

Fisher Onar, N. (2009). Neo Ottomanism, Historical Legacies and Turkish Foreign Policy. Discussion Paper Series -2009/03, Center for Economics and Foreign Policy Studies (EDAM).

Ghavam, S. A. Ali. (2007). International Relationship, perspectives and Theories. Tehran: Samt Publication.

Gholizadeh, Ali V., \& Zaki, Y. (2008). Analysis of Iran's Geopolitical and Geo-Economical Position for Caucasus and Central Asia Countries. Geopolitics Quarterly, 4(3), 21-56. [Persian]

Ghoryshi, S. H. R. (2002). Comparison between Definition of National Interest in Political Science and International Relationship. Military Management Magazine, 7, 35-56. [Persian]

Ghysari, N., \& Goudarzi, M. (2009). Iran and Armenia Relationship: Opportunities and obstacles. Central Eurasia Studies, 2(3), 121-144. [Persian]

Hafeznia, M. R., \& Afshordi, M. H. (2002). Caucasus Geopolitical Analysis, a Ground for Better Foreign Policy Design in the Region. Geographical Researches, 42, 19-37. [Persian]

Hashemi, G. R., (2005). Security in South Caucasus. Tehran: Institute for Political and International Studies.

Karakoc, A. (2009). Turkey's Relations with Iran \& the United Sates, a Shift in Alignment. Unpublished Master thesis, Naval Postgraduate School, Monterey, California.

Karami, J. (2007). Israel Military Doctrine. Tehran: Andishe Sazane Nour.

Koulai, E. (2010). Iran and South Caucasus Geopolitics. Geopolitics Quarterly, 6(1), 75-111. [Persian]

Mirfakhrai, S. H. (2004). Caspian Sea Legal Regime, From Divergence to Convergence. Law and Politics Studies, 10, 179-200. [Persian]

Mojtahedzadeh, P., \& Husainpouriyan, R., \& Karimipour, Y. (2007). Analysis of Iran's Foreign Policy Overlapping with Azerbaijan based on Geopolitical Realities. Modares Olume Ensani Quarterly, 12(2), 213- 255. [Persian]

Moshfeghifar, I. (2004). South Caucasus Military Development and Role of Regional and Cross Regional Powers. Central Asia and Caucasus Studies Quarterly, 46, 41-74. [Persian]

Mousavi, S. R. (2009). The Future of Caspian Sea. Central Asia and Caucasus Studies Quarterly, 65, 1-14.

Nicu Sava, I. (2004). Geopolitical Patterns of Euro - Atlanticism, a Perspective from South Eastern Europe. Conflict Studies Research Center, Central and Eastern Europe Series, 04/16.

Omidi, A., \& Rezai, F. (2011). Neo-Ottomanism in Turkey New Foreign Policy: Characteristics and Effects on Middle East. Foreign Policy Quarterly, 3(3), 231-267. [Persian]

Rafi, H., \& Mazloumi, I. (2012). Obstacles toward Cooperation of Iran and Turkey in Central Asia and Caucasus. Central Eurasia Studies, 5(10), 79-98. [Persian]

Ranjbar, M. (2006). Definition of National Interest from Different Points of View. Economic Magazine, 225, 166-181. [Persian]

Sadegh Zadeh, K. (2008). Iran's Strategy in the South Caucasus. Caucasian Review of International Affairs, 2(1), $1-7$.

Sinkaya, B. (2005). Turkey - Iran Relations in the 1990s and the Role of Ideology. Perception Journal of International Affairs, X(1), 1-16.

Taspinar, O. (2011). The Three Strategic Visions of Turkey. Us- Europe Analysis series, 50. March 8, 2011.

Tekin, A., \& Williams, P. (2011). Geo - Politics of the Euro - Asia Energy Nexus: The European Union, Russia and Turkey. UK: Palgrave Macmillan.

Vosoughi, S. (2008). Security Treats for Iran's Interests in South Caucasus Region. Political and International Studies Quarterly, Islamic Azad University of Shahreza, 1(1), 101-116. [Persian]

Yakushik, V. M. (2006). Contemporary Political Dispute over Caspian Sea Legal Regime. Trans: Ziba Farzinnia. Central Asia and Caucasus Studies Quarterly, 22, 21-34. [Persian] 


\section{Copyrights}

Copyright for this article is retained by the author(s), with first publication rights granted to the journal.

This is an open-access article distributed under the terms and conditions of the Creative Commons Attribution license (http://creativecommons.org/licenses/by/3.0/). 